\title{
NOTE
}

\section{Redundancy of macrobenthos from lagoonal habitats in the Adriatic Sea}

\author{
M. Mistri* , E. A. Fano, R. Rossi \\ Department of Biology, University of Ferrara, Via L. Borsari 46, 44100 Ferrara, Italy
}

\begin{abstract}
In a recent paper, Clarke \& Warwick (1998; Oecologia 113: 278-289) developed a method of quantifying the complementarity of species assemblages, and demonstrated that in some marine benthic communities the redundancy in community composition was remarkably high. The concept of structural and functional redundancy was tested using macrobenthic species abundance data from 2 eutrophic lagoons, the Valli di Comacchio and the Sacca di Goro, in the northern Adriatic Sea. Samples were collected at approximately seasonal intervals: the Comacchio data set spanned from November 1996 to January 2000, while the Goro data set was from January 1993 to December 1998. The level of structural redundancy in such habitats was quite low, while functional redundancy seemed higher. These findings are probably of great importance in considering conservation action and management of such habitats.
\end{abstract}

KEY WORDS: Complementarity · Macrobenthos · Lagoons Northern Adriatic Sea · Italy

Resale or republication not permitted without written consent of the publisher

Several hypotheses about changes in species diversity and community responses give great relevancy to the functional similarity among species: on the one hand is the idea that each species is unique, and its removal will have consequences on the functioning of the community (the rivet hypothesis; Ehrlich \& Ehrlich 1981); on the other hand is the more recent idea that species overlap in function to a sufficient degree that the removal of one species will be compensated by the others, with negligible overall consequences to the community (the redundancy hypothesis; Walker 1992, Lawton \& Brown 1993). By this viewpoint, redundancy in community composition implies that many species are interchangeable in the way that they characterize an assemblage. If those species are also functionally equivalent, the level of redundancy will be a measure

\footnotetext{
*E-mail: m.mistri@dns.unife.it
}

of assemblage resilience (Chapin et al. 1995). In marine benthic communities, the concept of redundancy was recently explored by Clarke \& Warwick (1998), and there appeared to be a remarkably high level of redundancy in the species assemblages that characterized community composition. Indeed, those authors quantified the extent of such a redundancy by extracting, through multivariate analyses, 4 response units, i.e., 4 small, mutually exclusive subsets of species well correlated to the wider community pattern. However, the benthic communities investigated were characterized by quite a high number of species (>200), which is a common feature in marine habitats. Species number is essential to long-term maintenance of a community (e.g., competiton, predation, mutualism) and an ecosystem (e.g., flows of energy and recycling of materials) processes over a complete cycle of common disturbance events (Chapin et al. 1995). Conversely, the fewer species there are (e.g., in a functional group) the more likely it is that any extinction event will alter the processes associated with that functional group (Holling 1986). In this study, we explored the concept of functional redundancy in soft-bottom macrobenthic assemblages from northern Adriatic lagoonal habitats. Dealing with a species data set of reduced consistency, our goal was to study whether the community still exhibited some kind of redundancy, or whether, for instance due to environmental constraints, the species complement in such habitats was so reduced that each species had an uninterchangeable functional response in the community.

The macrobenthic assemblages considered in this study came from 2 northern Adriatic, shallow-water lagoons, the Valli di Comacchio and the Sacca di Goro, both located in the Po River Delta area (northern Italy), in the Mediterranean Sea (Fig. 1). The Valli di Comacchio is a semi-enclosed lagoonal complex of about $100 \mathrm{~km}^{2}$, with an average depth of $1 \mathrm{~m}$, almost com- 


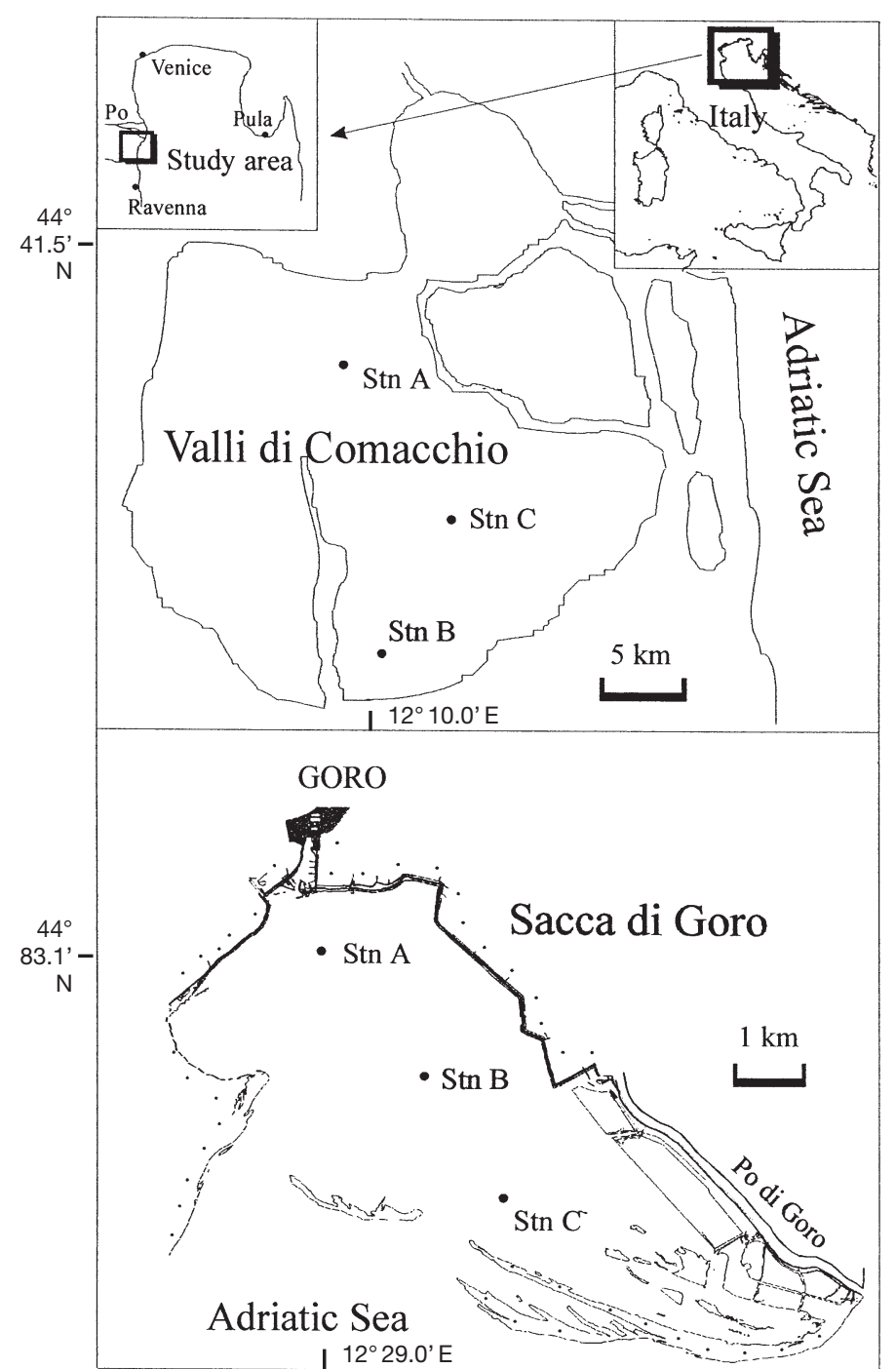

Fig. 1. Location of the 2 northern Adriatic shallow-water lagoons, the Valli di Comacchio and the Sacca di Goro (northern Italy)

pletely surrounded by earthen dikes, and separated from the sea by the highly anthropogenically impacted, $2.5 \mathrm{~km}$ wide Spina spit. The Sacca di Goro is a microtidal coastal lagoon with an area of approximately $26 \mathrm{~km}^{2}$, an average depth of about $1.5 \mathrm{~m}$, spatially enclosed by a long, natural sandbank. Both lagoons are affected by accelerated eutrophication processes due to excessive nutrient loads from both the entire Po River catchment area and local sources (Sorokin et al. 1996, Viaroli et al. 1996).

Methods and results. The Comacchio and Goro data sets consisted of species abundance counts from samples taken in triplicate at 3 stations in each lagoon at approximately seasonal intervals. The Comacchio data set spanned from November 1996 to January 2000, while the Goro data set was from January 1993 to
December 1998. Detailed information about sampling devices and procedure, and community composition is given elsewhere (Mistri et al. 2000, 2001a). For the present study, species counts from the 3 stations at each lagoon were combined and averaged. Following standard practice (Clarke \& Warwick 1994), species abundance was initially subjected to severe transformation (fourth root), to ensure that the multivariate analysis reflected the pattern of variation in the less-abundant taxa rather than being dominated only by the most common species. Bray-Curtis similarities (Bray \& Curtis 1957) were then computed between every pair of samples, and the resulting triangular similarity matrices were ordinated by means of non-parametric multidimensional scaling (MDS) (Kruskal \& Wish 1978).

The subset selection for our data sets, i.e., the smallest species subset for which the Spearman rank correlation $(\rho)$ with sample similarities for the full species set exceeds a predetermined value (set at $\rho=0.95$ ), was performed by using a 'forward selection backward elimination' algorithm (BVSTEP). A detailed explanation of the BVSTEP procedure is given in Clarke \& Warwick (1998). Having found the first species subset, in order to investigate whether there were further subsets of species which replicated the full community pattern, the species constituting the first response unit were excluded, and the algorithm re-run for the reduced species matrix against the full set. At this stage, a match for which the $\rho=0.95$ threshold is attained might not exist, and, in this case, the algorithm terminates at the optimum for $\rho$. This peeling procedure was then repeated in order to obtain a set of successive response units whose number should reflect the level of redundancy in the community matrix. Following standard practice (Clarke \& Warwick 1998), for each run of BVSTEP we used 40 random start and an initial subset of approximately $10 \%$ of the full species list. All analyses were done using the PRIMER v. 5.0 package (Clarke \& Warwick 1994), a suite of computer programmes developed at the Plymouth Marine Laboratory (UK).

The MDS ordination plot for the Comacchio complete data set (46 species) is shown in Fig. 2a. By means of the peeling procedure, we found 2 response units that attained the $\rho>0.95$ criterion. The best subset found comprised only 7 species, and the MDS plot based on this subset (Fig. 2b) showed a very close match to the wider community pattern exhibited by the complete data set. By re-applying the peeling procedure and excluding these 7 species (the first response unit) gave a second set of 13 species (Fig. 2c). Subsequent optimisations gave declining matches (3rd subset: 7 species, $\rho=0.86$; 4 th subset: 10 species, $\rho=$ 0.74 ) and the community pattern rapidly broke down (Fig. 2d). 

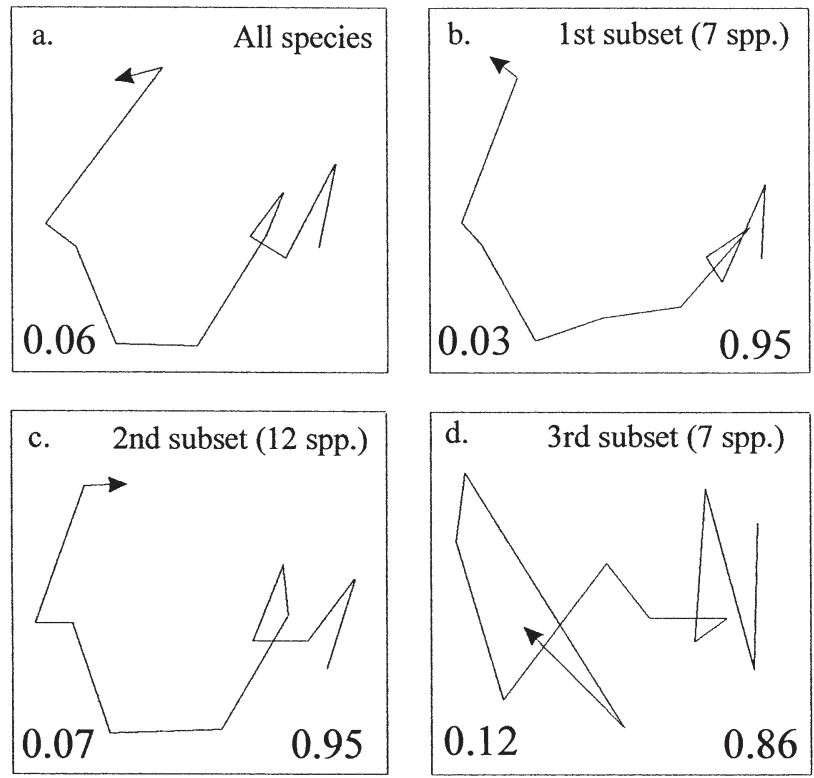

Fig. 2. Multidimensional scaling (MDS) plots from the Valli di Comacchio: (a) overall community pattern; $(b, c)$ mutually exclusive subsets of species which fully reproduce the (a) pattern; (d) third subset of species (note that notwithstanding the lower value of the matching coefficient $\rho$, the overall community pattern is still perceivable). On each plot, the MDS stress value (bottom left-hand corner) and the matching coefficient $\rho$ (bottom right-hand corner) are reported

The MDS plot for the Goro complete data set (52 species) is shown in Fig. 3a. The peeling procedure gave only 1 response unit, constituted by 12 species, which attained the $\rho>0.95$ criterion; the MDS plot based on this subset is shown in Fig. 3b. Subsequent optimisations gave immediately degrading matches, with the second subset of 15 species achieving a maximum correlation of 0.77 (Fig. 3c), and the third (8 species) giving only $\rho=0.41$ (Fig. 3d). Note that for both data sets, the MDS ordination of the respective first response unit showed a stress coefficient value lower than that of the overall MDS ordination. Species lists from the Comacchio and Goro macrobenthic analyses are reported in Tables 1 \& 2 respectively. In the tables, species in each response unit extracted by the peeling procedure were assigned into functional groups following Bianchi \& Morri (1985), Gambi \& Giangrande (1985), Russo et al. (1985), Russo (1989), Scipione (1989) and Gambi et al. (1992). For the few taxa not determined at the species level the information on feeding type was deduced from related species. At Comacchio, the first 2 best subsets comprised surface and subsurface deposit feeders (typically Annelida and a bivalve species), suspension feeders, grazers (only in Subset 1), and carnivores (only in Subset 2). At Goro, the only subset extracted was mainly constituted by suspension feeders (8 species), together with surface deposit feeders (2 species) and grazers (2 species).

In order to ascertain whether the abundance of the same functional groups of organisms in different response units varied in an asynchronous way, thus indicating some degree of change through time in ecosystem processes (Frost et al. 1995), transformed (fourth root) abundance of species within each functional category were summed and plotted against time (Fig. 4). Each aggregate group was representative of an ecosystem process. Although the pattern of change differed among functional groups, no evident changes in community structure and, thus, ecosystem processes were observed through the period of study at both lagoons. The following step was to investigate the occurrence of compensatory changes among functionally similar species. Transformed abundance of species from the subsets which matched the $\rho>0.95$ criterion was plotted against time. At the species level, there were both major declines and increases for some taxa during the study period. In Fig. 5, successful peelings of the surface deposit feeders from the 2 Comacchio subsets are shown. Compensatory responses seemed evident between Cirratulus sp. 1 and Amphitrite sp. 1 in the first subunit, and between Cirriformia tentaculata and Nereididae sp. 1 in the second subunit. Other species abundance varied synchronically, as well as grazers in Subset 1 and predators in Subset 2 (data not shown). In Fig. 6, abundance of species extracted from
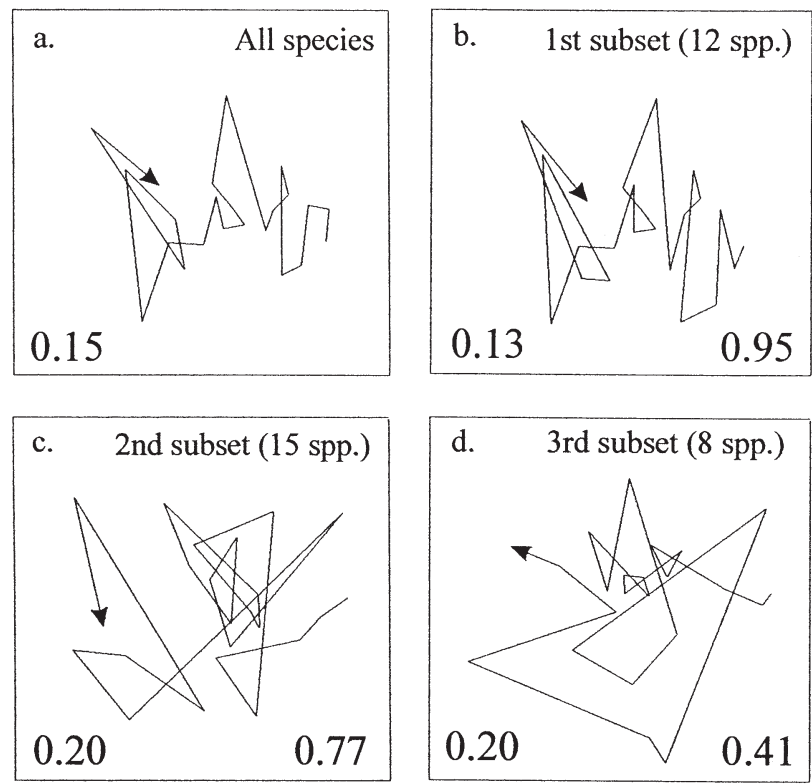

Fig. 3. MDS plots from the Sacca di Goro: (a) overall community pattern; (b) first response unit reproducing the overall pattern; $(c, d)$ further subsets of species extracted by the peeling procedure, but the overall community pattern is broken down. Coefficients on the plots as in Fig. 2 
the Goro data set is reported. For clarity, suspension feeders are shown in 2 plots: bivalve molluscs (Cerastoderma glaucum, Musculista senhousia, Mytilus galloprovincialis, and Mytilaster minimus) and others
(Ascidiacea sp. 1, Ficopomatus enigmaticus, and Hydroides dianthus). Compensation was evident both in the suspension feeder group ( $M$. senhousia increased in abundance outcompeting $M$. minimus and substan-

Table 1. Taxonomic composition of species subset from the peeling procedure of the lagoon of Valli di Comacchio. Spearman rank correlation value $(\rho)$ is also given

\begin{tabular}{|c|c|c|c|}
\hline $\begin{array}{l}\text { Subset } 1 \\
\rho=0.95\end{array}$ & $\begin{array}{l}\text { Subset } 2 \\
\rho=0.95\end{array}$ & $\begin{array}{l}\text { Subset } 3 \\
\rho=0.86\end{array}$ & $\begin{array}{l}\text { Subset } 4 \\
\rho=0.74\end{array}$ \\
\hline \multirow{4}{*}{$\begin{array}{l}\text { Surface deposit feeders } \\
\text { Neanthes succinea } \\
\text { Amphitrite sp. } 1 \\
\text { Cirratulus sp. } 1\end{array}$} & Surface deposit feeders & Surface deposit feeders & Surface deposit feeders \\
\hline & Syllidae sp. 1 & Streblospio shrubsolii & Hydrobia sp. 1 \\
\hline & Nereididae sp. 1 & Spio decoratus & Polycirrus sp. 1 \\
\hline & $\begin{array}{l}\text { Cirriformia tentaculata } \\
\text { Eunice sp. } 1\end{array}$ & Gibbula sp. 1 & Ampelisca abdita \\
\hline \multirow{2}{*}{$\begin{array}{l}\text { Subsurface deposit feeders } \\
\text { Oligochaeta }\end{array}$} & Tellina sp. 1 & Subsurface deposit feeders & Subsurface deposit feeders \\
\hline & $\begin{array}{l}\text { Corophium insidiosum } \\
\text { Corophium orientale }\end{array}$ & Capitella capitata & $\begin{array}{l}\text { Armandia cirrhosa } \\
\text { Chironomus salinarius }\end{array}$ \\
\hline \multirow{10}{*}{$\begin{array}{l}\text { Suspension feeders } \\
\text { Hydroides dianthus } \\
\text { Grazers-Scrapers } \\
\text { Tanaidacea sp. } 1 \\
\text { Microdeutopus gryllotalpa }\end{array}$} & & Suspension feeders & \\
\hline & $\begin{array}{c}\text { Subsurface deposit feeders } \\
\text { Heteromastus filiformis }\end{array}$ & Cerastoderma glaucum & $\begin{array}{l}\text { Grazers-Scrapers } \\
\text { Iphinoe sp. } 1\end{array}$ \\
\hline & & Grazers-Scrapers & Sphaeroma serratum \\
\hline & Suspension feeders & Melita palmata & Gammarus insensibilis \\
\hline & Ficopomatus enigmaticus & & \\
\hline & & Predators & Predators \\
\hline & Predators & Nemertea & Turbellaria \\
\hline & Actiniaria sp. 1 & & Phyllodoce lineata \\
\hline & Phyllodoce sp. 1 & & \\
\hline & Palaemon adspersus & & \\
\hline
\end{tabular}

Table 2. Taxonomic composition of species subset from the peeling procedure of the lagoon of Sacca di Goro. Spearman rank correlation value $(\rho)$ is also given

\begin{tabular}{|c|c|c|}
\hline $\begin{array}{l}\text { Subset } 1 \\
\rho=0.95\end{array}$ & $\begin{array}{l}\text { Subset } 2 \\
\rho=0.77\end{array}$ & $\begin{array}{c}\text { Subset } 3 \\
\rho=0.41\end{array}$ \\
\hline $\begin{array}{l}\text { Surface deposit feeders } \\
\text { Hydrobia sp. } 1 \\
\text { Corophium insidiosum }\end{array}$ & $\begin{array}{l}\text { Surface deposit feeders } \\
\text { Polydora ciliata } \\
\text { Bittium reticulatum } \\
\text { Abra ovata }\end{array}$ & $\begin{array}{l}\text { Surface deposit feeders } \\
\text { Neanthes succinea } \\
\text { Nereididae sp. } 1 \\
\text { Chrysallida sp. } 1\end{array}$ \\
\hline $\begin{array}{l}\text { Suspension feeders } \\
\text { Ficopomatus enigmaticus } \\
\text { Hydroides dianthus } \\
\text { Scapharca inaequivalvis } \\
\text { Mytilus galloprovincialis } \\
\text { Mytilaster minimus } \\
\text { Musculista senhousia } \\
\text { Cerastoderma glaucum } \\
\text { Ascidiacea sp. } 1 \\
\\
\text { Grazers-Scrapers } \\
\text { Gammarus aequicauda } \\
\text { Microdeutopus gryllotalpa }\end{array}$ & $\begin{array}{l}\text { Subsurface deposit feeders } \\
\text { Pectinaria koreni } \\
\text { Chironomus salinarius } \\
\text { Suspension feeders } \\
\text { Balanidae sp. } 1 \\
\text { Grazers-Scrapers } \\
\text { Haminoea hydatis } \\
\text { Caprella sp. } 1 \\
\text { Idotea baltica } \\
\text { Sphaeroma serratum } \\
\\
\text { Predators } \\
\text { Turbellaria } \\
\text { Cyclope neritea } \\
\text { Hinia reticulatus } \\
\text { Mysta picta } \\
\text { Brachynotus sexdentatus }\end{array}$ & $\begin{array}{l}\text { Subsurface deposit feeders } \\
\text { Capitella capitata } \\
\text { Predators } \\
\text { Actiniaria } \\
\text { Carcinus aestuarii } \\
\text { Eriphia sp. } 1 \\
\text { Palaemon elegans }\end{array}$ \\
\hline
\end{tabular}


Fig. 4. Sums of species abundance (fourth root transformed) within functional groups (SDF: surface deposit feeders; SSDF: subsurface deposit feeders; SF: suspension feeders; SC-GR: scrapers and grazers; PR: predators) plotted against time (Comacchio: N6, November 1996 ... etc; Goro: January, April, September, November of each year, except the last sample, which was collected in December instead of November)
Comacchio
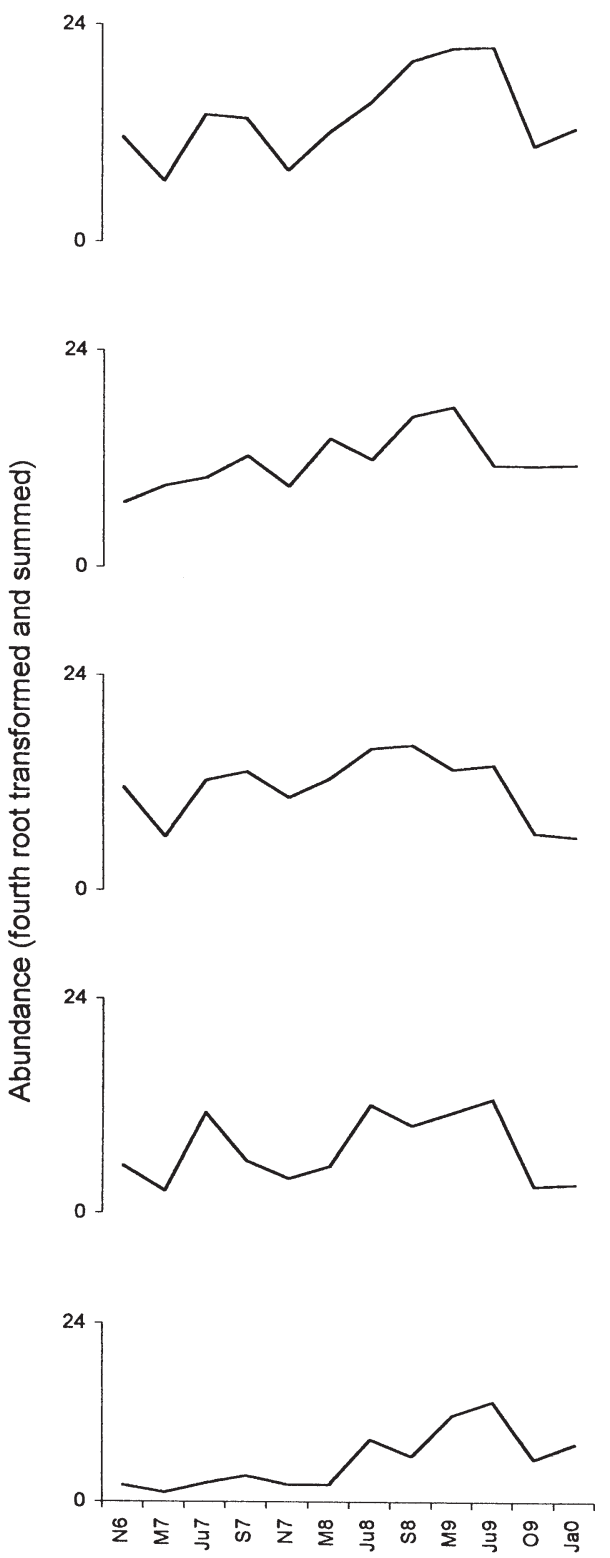

Goro
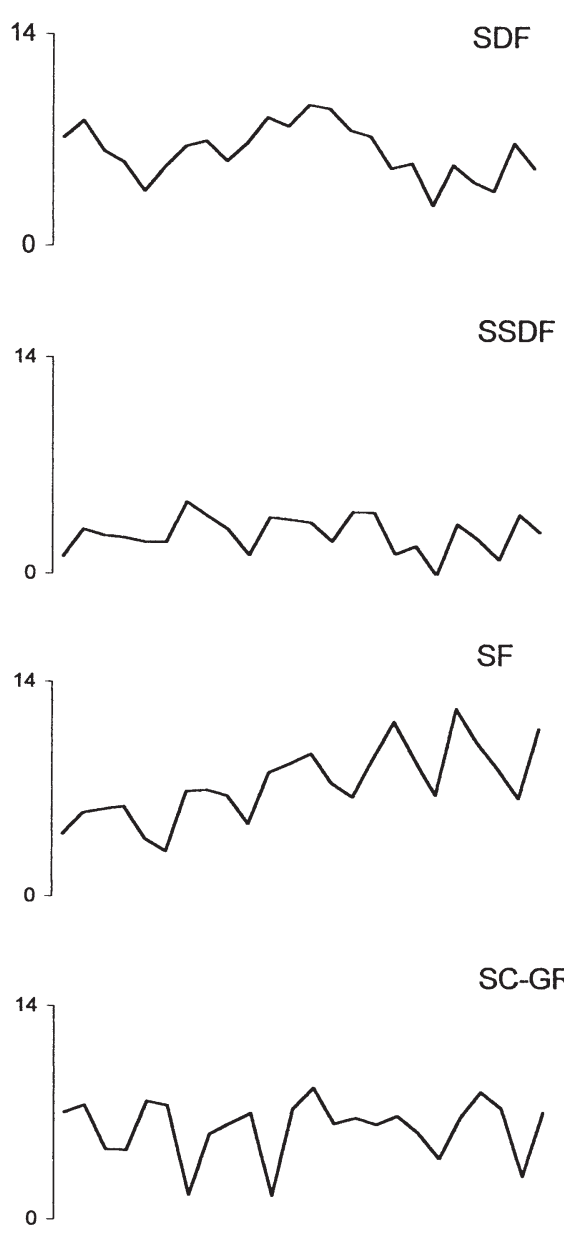

PR

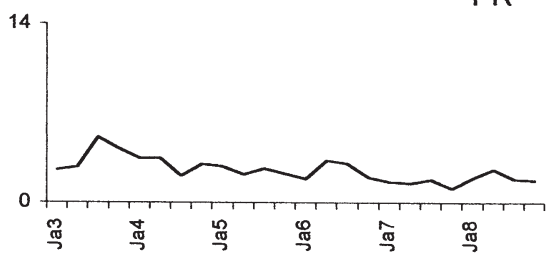

Time

tially reducing the abundance of the other suspensionfeeding species), and in the surface deposit feeder group, while grazers varied synchronically.

Discussion. Redundancy occurs when ecosystem processes are maintained at a constant level, despite stresses that induce shifts in the populations driving those processes (Frost et al. 1995). It must be stressed, however, that the peeling procedure adopted results in a measure of structural redundancy (Clarke \& Warwick 1998), and the link between this and aspects of functional redundancy might be somewhat equivocal. Our data suggest that some habitat types probably have naturally lower structural redundancy than others. Different numbers of response units correlated to the wider community pattern with a matching coefficient of $\rho>0.95$ were extracted by the peeling procedure in the 2 lagoons studied. Two subunits were extracted at Comacchio and only 1 at Goro. Thus, the structural redundancy of lagoonal benthic assemblages seems quite reduced with respect to that of marine habitats. In fact, at the 2 marine sites (the Bay of Morlaix, France, and an area off Northumberland coast, UK), where the redundancy of benthic communities was studied, the number of successful peels 


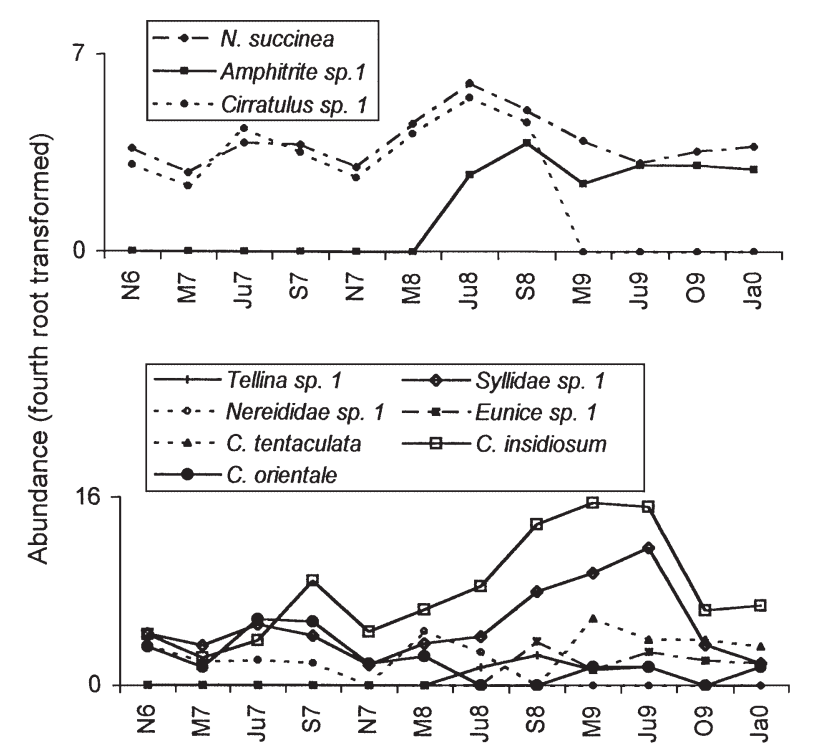

Fig. 5. Valli di Comacchio. Surface deposit feeder species abundance against time from the first (upper panel) and the second (lower panel) subsets successfully extracted

was 4 (Clarke \& Warwick 1998). This observation probably reflects the effects of ecological and evolutionary mechanisms which act to determine lagoonal community composition, and that only a restricted number of taxa have evolved species capable of tolerating the physiologically stressful condition that prevail in lagoonal habitats, with their strongly fluctuating environmental parameters.

The analysis of our response units revealed some consistent features among the Comacchio and Goro data sets. Firstly, it was evident that the overall community pattern at both lagoons was regulated by certain species (those that were extracted by the peeling procedure) with a strong signal-to-noise ratio through time. The fact that, for both data sets, the MDS stress value for the first subunit extracted was lower than that of the complete community ordination was probably indicative of a significant reduction of the noise in that data set. Secondly, the functional composition of the subunits was strongly indicative of differences in major energetic pathways driving the benthic communities inhabiting the 2 lagoons. Each of the response units encompassed quite a narrow taxonomic and functional spread. Comacchio was mostly characterized by detritivorous polychaetes, while Goro comprised almost exclusively suspension-feeding bivalves, thus suggesting that, in both habitats, the total community pattern was driven by different groups of organisms particularly adapted to local environmental conditions and resource availabilities. This narrow functional spread would seem to be indicative of quite a high functional redundancy; it is known (Chapin et al. 1995) that compensatory responses are most likely to occur when there are many species per functional group, and, indeed, some degree of species compensation among certain guilds seemed evident in both lagoonal benthic communities.

It is generally recognised (Frost et al. 1995) that the addition or loss of non-keystone species has a small effect on ecosystem or community functions. When species are similar to one another in their resource requirements, the gain or loss of a species has large effects on community composition, but less effect on ecosystem processes because of the compensatory responses of other species to the altered competitive environment (Chapin et al. 1995). At the species level, some degree of compensation seemed evident among surface deposit feeders: those species may have broad overlap in their diet (Gambi \& Giangrande 1985), such that a change in abundance of one species is compensated by changes in abundance of competing species,

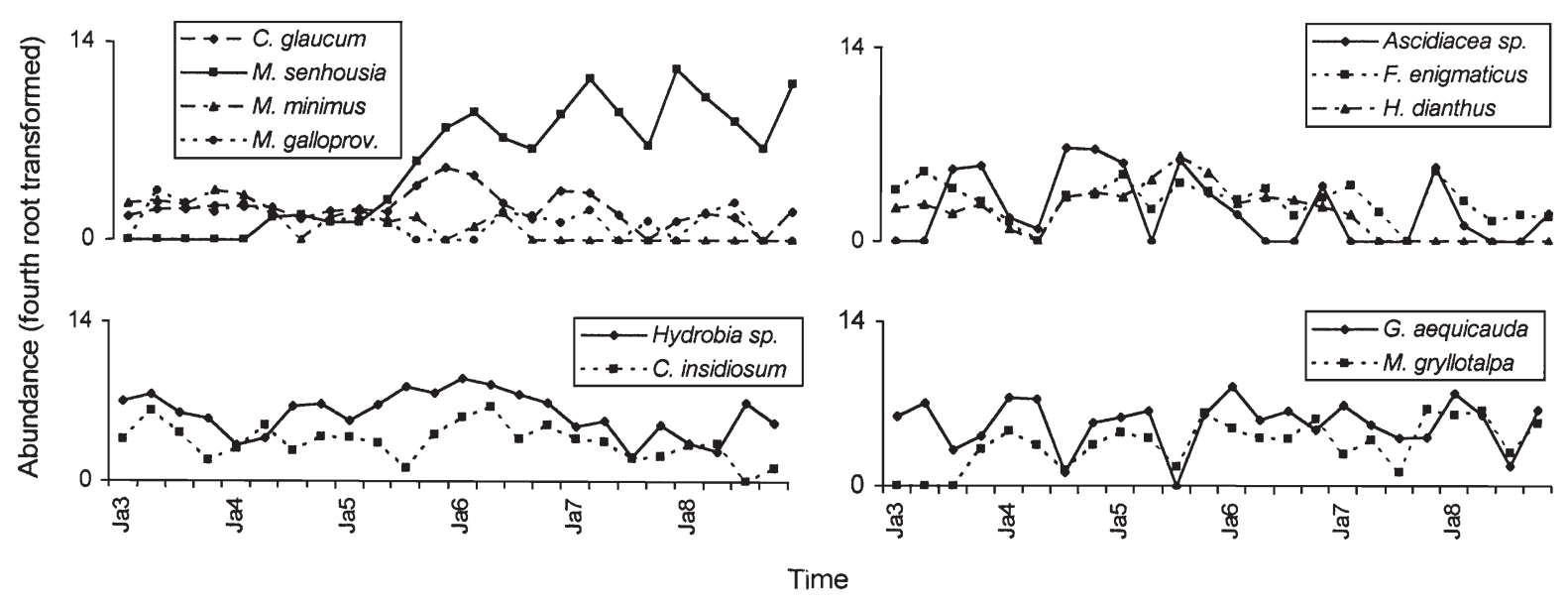

Fig. 6. Sacca di Goro. Abundance of species in successfully extracted functional groups against time (for further details see text) 
with minimal effect on ecosystem process. Moreover, in the Sacca di Goro the dynamics of the suspension feeder group seems to be driven by the bivalve Musculista senhousia. The accidental introduction of this species (in the Sacca di Goro, earlier findings of this allochthonous species are dated 1991-92; Turolla 1999) had overwhelming effects on its own functional group (Mistri et al. 2001b); within mussel mats, substantial decrease of abundance of other bivalve species has been reported (Crooks 1998, Crooks \& Khim 1999). Our observation that an invading species causes substantial changes in the community, but does not affect the ecosystem processes, is in accordance with the ideas of Vitousek (1990).

The number of species and their functional spread can be regarded as an insurance against large changes in ecosystem or community processes in response to disturbance or environmental change (Chapin et al. 1995). The Valli di Comacchio community, whose successive subunits (including Subset 3 as a 'near missed' response unit) contained several representatives of the functional groups expected to occur in such a habitat, exhibited some degree of both structural and functional redundancy. Since redundancy reflects the resistance to change of community functioning (Lawton \& Brown 1993), we hypothesise that the benthic community of the Valli di Comacchio is quite resistant to disturbance or environmental changes, despite stresses (Mistri et al. 2000) that generate fluctuations in species abundance. The case of the community of the Sacca di Goro was different. Because of low structural redundancy we hypothesise that any extreme event that affects in toto the suspension-feeding bivalve assemblage in the Sacca di Goro (e.g., prolonged anoxia, acute pollution, diseases) will probably have profound implications on the community functioning of that ecosystem. On the contrary, because of some degree of functional redundancy, any event that affects some specific component of that guild (e.g., overexploitation) will be buffered by compensation mechanisms. These conclusions are essential considering conservation actions and sustainable management of the Sacca di Goro, which is a lagoon subjected to intense bivalve fisheries. Any unusual extreme event perturbing the bivalve community of the Sacca di Goro is likely to force that system into another domain, with unpredictable changes in its functioning and potential adverse consequences to the local fishery.

With this note we demonstrated that the faunal communities of certain habitats exhibit a different level of structural and functional redundancy with respect to others, and we speculated on the potential for compensation of such communities. It must be stressed that the link between redundancy and potential for compensation is probably equivocal, and our hypotheses should be considered with caution; in fact, only manipulation experiments dealing with the removal of species can test if there is compensation within guilds or functional groups.

Acknowledgements. This study is part of a topic 'Production, change and vulnerability of transitional aquatic environments along the Adriatic coast' supported by the Italian Ministry of University, Scientific and Technological Research (MURST, COFIN99). The manuscript benefited from comments given by 4 anonymous reviewers.

\section{LITERATURE CITED}

Bianchi CN, Morri C (1985) I Policheti come descrittori della struttura trofica degli ecosistemi marini. Oebalia 11: $203-214$

Bray JR, Curtis JT (1957) An ordination of the upland forest communities of Southern Wisconsin. Ecol Monogr 27: 325-349

Chapin FS, Lubchenco J, Reynolds HL (1995) Biodiversity effects on patterns and processes of communities and ecosystems. In: Heywood VH (ed) Global biodiversity assessment. Cambridge University Press, Cambridge, p 289-301

Clarke KR, Warwick RM (1994) Changes in marine communities: an approach to statistical analysis and interpretation. Plymouth Marine Laboratory, Plymouth

Clarke KR, Warwick RM (1998) Quantifying structural redundancy in ecological communities. Oecologia 113:278-289

Crooks JA (1998) Habitat alteration and community-level effects of an exotic mussel, Musculista senhousia. Mar Ecol Prog Ser 162:137-152

Crooks JA, Khim HS (1999) Architectural vs. biological effects of a habitat-altering, exotic mussel, Musculista senhousia. J Exp Mar Biol Ecol 240:53-75

Ehrlich PR, Ehrlich AH (1981) Extinction. The causes and consequences of the disappearance of species. Random House, New York

Frost TM, Carpenter SR, Ives F, Kratz TK (1995) Species compensation and complementarity in ecosystem function. In: Jones CG, Lawton JH (eds) Linking species and ecosystems. Chapman \& Hall, New York, p 224-239

Gambi MC, Giangrande A (1985) Caratterizzazione e distribuzione delle categorie trofiche dei Policheti nei fondi mobili del Golfo di Salerno. Oebalia 11:223-240

Gambi MC, Lorenti M, Russo GF, Scipione MB, Zupo V (1992) Depth and seasonal distribution of some groups of the vagile fauna of the Posidonia oceanica leaf stratum: structural and trophic analyses. PSZN I: Mar Ecol 13:17-39

Holling CS (1986) Resilience of ecosystems: local surprise and global change. In: Clark WC, Munn RE (eds) Sustainable development and the biosphere. Cambridge University Press, Cambridge, p 292-317

Kruskal JB, Wish M (1978) Multidimensional scaling. Sage, Beverly Hills

Lawton JH, Brown VK (1993) Redundancy in ecosystems. In: Schulze ED, Mooney HA (eds) Biodiversity and ecosystem function, Springer-Verlag, Berlin, p 255-270

Mistri M, Fano EA, Rossi G, Caselli K, Rossi R (2000) Variability in macrobenthos communities in the Valli di Comacchio, northern Italy, an hypereutrophized lagoonal ecosystem. Estuar Coast Shelf Sci 51:599-611

Mistri M, Rossi R, Fano EA (2001a) Structure and secondary production of a soft bottom macrobenthic community in a 
brackish lagoon (Sacca di Goro, northern Italy). Estuar Coast Shelf Sci (in press)

Mistri M, DalZotto W, Rossi R (2000b) Stime preliminari sulla crescita e la produzione secondaria del mitilide allocrono Musculista senhousia nella Sacca di Goro. Atti $32^{\circ}$ Congresso S.I.B.M., Numana 4-9 Giugno 2001 (in press)

Russo GF (1989) La scelta dei descrittori morfo-funzionali nell'analisi dei sistemi bentonici: un approccio con la componente malacologica di una preteria a Posidonia oceanica. Oebalia 15:213-228

Russo GF, Fresi E, Scardi M (1985) Il popolamento a molluschi dei fondi mobili del Golfo di Salerno: analisi strutturale in rapporto al trofismo. Oebalia 11:339-348

Scipione MB (1989) Comportamento trofico dei Crostacei Anfipodi in alcuni sistemi bentonici costieri. Oebalia 15: 339-348

Editorial responsibility: Otto Kinne (Editor),

Oldendorf/Luhe, Germany
Sorokin Yu I, Sorokin P Yu, Gnes A (1996) Structure and functioning of the anthropogenically transformed Comacchio lagoonal ecosystem (Ferrara, Italy). Mar Ecol Prog Ser 133: $57-71$

Turolla E (1999) Nuovi ospiti per la Sacca di Goro. Laguna 4/99:32-35

Viaroli P, Naldi M, Bondavalli C, Bencivelli S (1996) Growth of the seaweed Ulva rigida C. Agard in relation to biomass densities, internal nutrient pool and external nutrient supply in the Sacca di Goro. Hydrobiologia 329: 93-103

Vitousek PM (1990) Biological invasions and ecosystem processes: towards an integration of population biology and ecosystem studies. Oikos 57:7-13

Walker BH (1992) Biodiversity and ecological redundancy. Conserv Biol 6:18-23

Submitted: October 2, 2000; Accepted: January 18, 2001

Proofs received from author(s): March 26, 2001 